Article

\title{
Sustainability and EMAS: Impact of Motivations and Barriers on the Perceived Benefits from the Adoption of Standards
}

\author{
José Álvarez-García ${ }^{1}$ and María de la Cruz del RíoRama ${ }^{2, *}$ \\ 1 Accounting and Financial Economy Department, Faculty of Finance, Business and Tourism, \\ University of Extremadura, 10071 Caceres, Spain; pepealvarez@unex.es \\ 2 Business Organisation and Marketing Department, Faculty of Business Administration and Tourism, \\ University of Vigo, 32004 Ourense, Spain \\ * Correspondence: delrio@uvigo.es; Tel.: +34-988-38-87-27 \\ Academic Editor: Vincenzo Torretta \\ Received: 28 July 2016; Accepted: 13 October 2016; Published: 20 October 2016
}

\begin{abstract}
The objective of this paper is to analyze the influence of the sources of motivation that lead companies to adopt a global standard of the Environmental Management System and the barriers found in the process, on the perceived benefits of the implementation and certification of the standard. To achieve the objectives proposed, primary data were collected using a survey questionnaire that was administered to a representative sample of companies certified as EMAS-Eco-Management and Audit Scheme of the Autonomous Community of Galicia (sample of 114 of the 255 companies). An extensive review of the academic literature published on ISO 14001 and EMAS about motivations, barriers and benefits was carried out in order to establish the working hypotheses that are analyzed using structural equation models as the statistical tool. The findings of this study show that the motivations positively affect the benefits derived from implementation, noting that the internal motivations (related to efficiency; improved performance, productivity and profitability) have a stronger influence on the benefits than the external motivations (related to stakeholders' social pressure). In addition, the motivations also affect the perceived barriers, and these affect the benefits negatively, i.e., the higher the barriers encountered, the lower the perceived benefits. The results obtained allow us to identify important implications for managers, which will help them establish management strategies in the field of environmental management.
\end{abstract}

Keywords: environmental management; sustainability; EMAS III; motives; barriers; benefits; Spain

\section{Introduction}

Environmental management carried out by companies in order to reduce the environmental impact of their activities on the environment has become in recent years a competitive advantage for those companies wishing to operate in national and international markets [1]. A competitive advantage is derived both from the image transmitted by managing the company following environmental guidelines and standards and from improved internal efficiency of the organization resulting from this management [2].

This management is performed by implementing Environmental Management Systems (EMSs). EMSs are defined in the EMAS III Regulation [3] as "part of the general management system which includes the organizational structure, planning of activities, responsibilities, practices, procedures, processes and resources for developing, implementing, carrying out, reviewing and maintaining the organization's environmental policy" and by Steger [4] (p. 24) as a "transparent, systematic process known corporate-wide, with the purpose of prescribing and implementing environmental goals, policies and responsibilities, as well as a regular auditing of its elements". The most used 
and best known are the international ISO 14001 standard created by the International Organization for Standardization (ISO) and the EU's EMAS, currently known as EMAS III-Eco-Management and Audit Scheme [5], the result of the second revision of the Regulation previously called EMAS I and II. EMAS III is a voluntary regulation of the European Union, and ISO 14001 is international in scope. Both Environmental Management Systems have the same guarantees, are equally reliable and are very similar, the EMAS regulation being the most restrictive.

The figures concerning the number of ISO 14001 and EMAS III-certified companies justify the choice of Spain as a target population of this research, as Spain is shown as a country with great sensitivity by its companies to protect the environment and with the environmental impact they cause. Spain was the first European country in the number of certified EMAS III organizations in 2015, ahead of Italy and Germany, with a quarter of the 4500 organizations certified in Europe [6], with Catalonia, Galicia and Madrid the regions with the highest number of registered organizations, which account for $65 \%$ of the total (Ministry of Agriculture, Food and Environment). Moreover, it is in the fifth place worldwide and second in Europe behind China, Italy, Japan and the United Kingdom with 16,051 ISO 14001 certifications in 2014.

There are many researchers who claim that the implementation of these systems helps to improve environmental performance $[7,8]$ and allows for numerous benefits, including business performance (internal operational improvements) [8,9], improved corporate image [9], people and customer results $[10,11]$ and financial results $[12,13]$, but its implementation is not free of barriers to overcome. There has been numerous research with the aim of analyzing the motivations driving companies to their implementation [11,14-19], barriers to be overcome in this process [20-23] and also on the perceived benefits of the implementation of EMSs $[7-9,18,24,25]$ with the certainty that these can encourage companies to continue investing in this area [26].

However, studies examining the relationship between the motivations that lead to implement EMSs, barriers to overcome and the benefits of implementation and certification are very scarce. Therefore, we propose this study in order to fill this gap. Thus, the aim of this paper is to analyze whether the motivations driving companies to implement EMSs affect the perception of the barriers they have to overcome and the perceived benefits of implementation and certification. For this, a theoretical structural model that includes the causal relationships based on theory among the three concepts is proposed. In order to evaluate the work hypotheses, we conducted a survey of 114 companies certified as EMAS III in Galicia (Spain) and were validated using Structural Equation Modeling (SEM), a technique that provides both the structure of causal relationships and the importance of the effect of each of the constructs on the benefits.

The rest of this paper is structured as follows. Firstly, we review the literature on Environmental Management Systems, in particular with reference to their motivations for implementing, barriers encountered and benefits obtained from the implementation of EMSs. A theoretical model and hypotheses are established. In our study, in the following section, the methodology used is described (sample, survey process and data analysis), while the third one includes the analysis of the results. The final section gives the main conclusions, implications of the work and limitations, and the future lines of research are proposed.

\section{Theoretical Model and Hypotheses}

\subsection{Motivations}

The literature review allows us to observe that there are two main approaches regarding the types of motivations that lead companies to implement EMSs. The first approach refers to external factors related to external pressures that can come from the market, society and regulations both at the national and international level. The second approach focuses on the motivations related to internal improvement of the organization that can be achieved with the implementation of EMSs and allow for improved performance, productivity and profitability, which lead to achieving a sustainable source of competitive advantage [27-32]. 
In this sense, many are the motivations found by studies conducted and forming part of both approaches, which are not mutually exclusive and reinforce each other [33]. Among those, we can mention (in Heras et al. [34] (p. 195), you can see a summary of the empirical literature on the motivations for adopting the ISO 14001 standard):

- Satisfying pressure from customers, suppliers and other stakeholders [9,14,15,35-37].

- $\quad$ Ensuring compliance with the legislation $[11,14,17,35]$.

- Improvement in environmental performance [35,38,39].

- Improving the image that the company offers its customers $[9,17,35,38,39]$.

- $\quad$ Cost reduction [9,14,35,37].

- Others: senior management concern [14], increase in efficiency, competitiveness and productivity [15,36,37], new market opportunities and continuous improvement [37].

As has been demonstrated, there are many reasons that can lead a company to implement EMSs, and therefore, there are many researchers in this field who have tried to group them. Bansal and Roth [40] identified three groups of motivations: ethical, competitive and relational motives. The first type refers to the concern of the company to respond to its sense of ecological responsibility. The second group leads the company to implement EMSs in search for competitive advantages, which respond to the objective of improving profitability, and the third group refers to the implementation of environmental practices to adapt their functioning to the rules and thus become legitimized, which allows them to improve their relationships with their stakeholders through their environmental practices.

Along the same lines, for Neumayer and Perkins [41], there are two main groups of motives: internal motives related to efficiency (improved performance, productivity and profitability) and external or institutional motives related to stakeholders' social pressure. For González-Benito and González-Benito [16], there are four motives: operational competitive motives (costs, productivity), commercial competitive motives (market, image and customers), ethical motivations and relational motivations (legislators, local organizations). Gavronski et al. [18] grouped them into reactive, internal, legal and proactive motives.

\subsection{Barriers}

When companies implement EMSs they have to face different barriers, the most important being the high investment required for the effective performance of these systems [7] (p. 205). However, this is not the only barrier, as there are many that have to be faced. Post and Altman [42] group these barriers into industrial barriers and organizational barriers. The first group refers to technical information, capital costs, the configuration of current operations, competitive pressures and industry regulations and the second group to the attitude of employees, available resources, lack of communication, insufficient leadership from senior management and inadequate organizational structure $[10,25,43,44]$.

In this regard, there are several studies investigating barriers. For Quazi [45], the barriers detected are the complexity of the ISO standards, legal ramifications and the lack of incentives to implement a system of this type, the lack of management commitment, the lack of employee involvement, implementation costs and unclear responsibilities of employees. Del Brio et al. [46] conducted a study in Spanish companies and identified barriers, such as lack of knowledge of environmental requirements [47], non-existence in the business sector with the adopted system [48], high cost of implementation and maintenance [49], lack of resources in the enterprise [50], lack of senior management commitment [48], lack of customer commitment [51], negative impact on benefits [47], little support from public administrations $[47,50]$ and workers, lack of flexibility, reduced benefits and little support of management.

Poksinska et al. [25] identified in their study that the barriers to overcome are related to environmental aspects and training, with the commitment of management, documentation to generate, periodic audits, implementation of corrective actions, (re)definition of standard procedures, commitment of workers and capital investment. 
On the other hand, Hillary [10] identified 48 barriers, which were grouped into resources, understanding and perception, application, attitudes and corporate culture, certifiers, the economy, institutional weaknesses, support and guidance. That same year, Zutshi and Sohal [11] (p. 339) performed a detailed review of the literature on barriers (33 investigations), which they summarized as follows: "(1) costs required for implementation and certification (training, audit fees, audit), as well as maintenance costs; lack of available resources and external support (technical or economic) obtained either from subsidies or aid for SMEs, clear guidelines for their application in companies with non-regular workers, as in the construction sector; lack of established guidelines for setting goals and objectives and degree of participation of employees, suppliers and other stakeholders; lack of guidelines on how to bring continuous improvement; interpretation of standard terms". Turk [52] mentions that the disadvantages of obtaining the ISO 14001 include high initial and operating costs, lack of qualified staff and lack of sufficient information on the certificates.

\subsection{Benefits}

The benefits derived from the implementation and certification of EMSs have been extensively studied in the academic literature [53], although there are also studies indicating negative aspects and weaknesses arising from the implementation [54]. A detailed review of the literature on the benefits of EMSs can be seen in the work of Zutshi and Sohal [11], Claver et al. [55], Molina-Azorín et al. [56], Heras et al. [34] (p. 198), Tarí et al. [53] and Martín-Peña et al. [26]. There are many benefits, tangible and intangible or economic and organizational ones that can be attributed to the implementation of EMS. These studies have shown the positive effects of the certification of EMSs on different areas:

- Improvement in operational processes $[10,57,58]$.

- Cost reductions and improvement in productivity $[9,11,18,24,25]$.

- Minimization of environmental problems [17,18,58-60].

- Improvement in product/service quality [58].

- Improved image [10,11,18,36,61,62].

- Compliance with laws and regulations [15,34,59].

- Increase in competitiveness [10,18,24,29].

- Improvement in environmental performance [8,63-66].

- Improvement in relationships with stakeholders [11,25].

- Improvement in financial performance $[16,24,67,68]$.

Given the amount of benefits attributed to EMSs, several researchers have tried to group them. Thus, Pakosinska et al. [25] distinguish between internal performance, external commercialization and the benefits of relationships. Hillary [10] distinguishes between internal and external benefits. Link and Naveh [8] distinguish between environmental performance and business performance. Gavronski et al. [18] emphasize four groups: productivity benefits, financial benefits, market benefits and benefits for society. Tarí et al. [53] (p. 304) after performing a literature review (29 papers were identified regarding the benefits of ISO 14001) state that "the three benefits most considered identified by the studies are environmental performance, efficiency and profitability. Other benefits which are also worth mentioning are improved image, customer satisfaction, improved staff results, competitiveness and relationships with stakeholders. On the other hand, the benefits least considered in the empirical studies analyzed are sales, improved product quality and increased market share".

\subsection{Motivations-Barriers-Benefits}

There are no studies examining whether there is a relationship between the motivations that lead companies to implement EMSs and the barriers encountered that must be dealt with when implementing the system. However, there are studies examining the relationships between organizational culture and Total Quality Management (TQM) implementation barriers. The work 
in [69-72] defined this as a set of commonly accepted attitudes, values and beliefs that guide the behavior of the members of an organization [73]. These studies validate empirically, in the case of the implementation of systems quality management, that an organizational culture focused in our case on an environmental approach reduces barriers to the implementation of environmental management systems (top management barriers, employee barriers and process management barriers).

Therefore, considering the literature, we think that companies that begin the process with high levels of motivation have encouraged an environmental organizational culture that implies a strong commitment from top management with the implementation process of EMSs, adequate allocation of human and material resources to achieve successful implementation, having adequately motivated staff, on which successful implementation depends, and that show great company concern for issues related to environmental management. As a result, we think that the higher the motivation level, the lower the perceived barriers. We propose the following hypotheses:

H1. External motivations negatively influence the perception of the barriers encountered in the implementation of EMAS (the higher the motivation, the lower the level of barriers encountered).

H2. Internal motivations negatively influence the perception of the barriers encountered in the implementation of EMAS (the higher the motivation, the lower the level of barriers encountered).

Many empirical studies validate empirically that there is a relationship between the motivations and benefits achieved (environmental performance, efficiency and profitability, among others) from the implementation of EMSs, and it is positive, i.e., the higher the internal or external motivational level, the higher the degree of perceived benefits [24,34,56,58,74-76]. For these reasons, we propose the following hypotheses:

H3. External motivations to implement EMAS positively affect the benefits obtained from implementation.

H4. Internal motivations to implement EMAS positively influence the benefits obtained from implementation.

On the other hand, the barriers that make the adoption of the EMAS standard difficult slow down the process and therefore affect the managers' perception on the benefits of using EMS. Therefore, we propose the following hypothesis:

H5. Companies that have found more barriers when implementing EMAS have profited less from its implementation.

To summarize, in Figure 1, a sequence diagram or "path diagram" is shown with all of the first-order latent variables, including the hypotheses to be contrasted, that make up the theoretical model to be tested in this research.

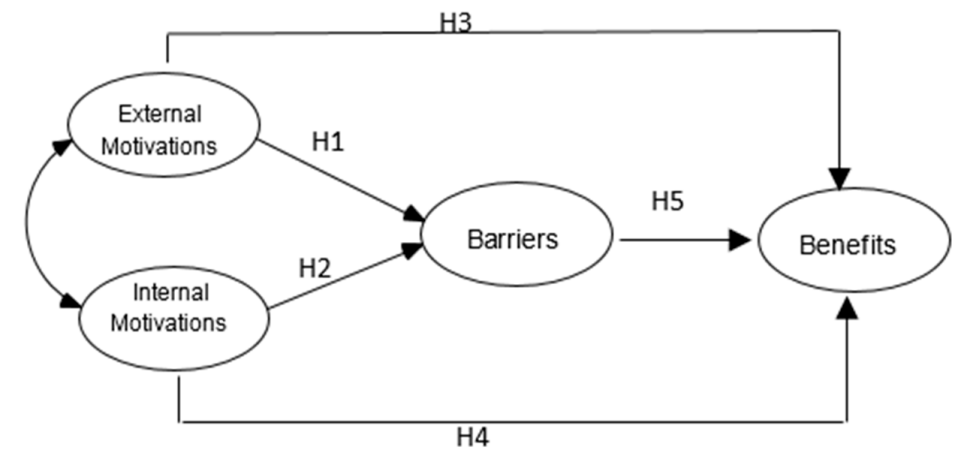

Figure 1. Study model. Source: authors' own data. 


\section{Methodology}

\subsection{Sample and Survey Process}

The target population of this study is the companies certified as EMAS III in Galicia (Spain) belonging to the industrial and service sector, in total 255 companies $(73.2 \%$ service sector, $23.6 \%$ secondary sector and $3.2 \%$ primary sector). The questionnaire was sent to all of them, and 114 completed questionnaires were received, which represents a response rate of $44.70 \%$, acceptable taking into account the existing literature on the subject [77]. Regarding the sampling error, it is $6.84 \%$ for a confidence level of $95 \%$ and the least favorable situation of $p=q=0.5$.

The questionnaire was sent by email, and telephone contact was used, after sending several emails, in order to improve the response rate. Regarding the final sample, if we consider the company sectors, 69 belong to the service sector ( $36.50 \%$ total population), 38 to the secondary sector $(64.40 \%$ total population) and 7 to the primary sector ( $100 \%$ total population).

Before sending the final questionnaire, 20 subjects were selected (managers of the company, the sample and experts in the field of environmental management), and we carried out a pretest to confirm its validity and the clarity of the questions. The instrument was revised on the basis of their suggestions.

The data were obtained by administering a structured questionnaire survey. The questionnaire includes questions that allow us to explore and measure the motivations, barriers and benefits in the implementation of EMAS III (Appendix A). All of the scales used in measuring the variables were adapted from the empirical literature $[10,11,16-18,35,37,46,75,78]$. To measure motivations and benefits, 6 and 7 items were used respectively, and the respondents were required to choose a value from a 5-point Likert scale ( $1=$ not at all important, 5 = very important); in the case of the barriers, we used 4 items ( 1 = very easy, 5 = very difficult $)$ on a 5 -point Likert scale.

A limitation of this research is derived from the methodology used to obtain the data. The information comes from the perception of managing directors or quality managers, so it is likely that responses are biased [79]. In order to overcome this limitation, Harman's single factor test was applied, a test suggested by Podsakoff and Organ [80] and used by other researchers, such as Psomas et al. [81], Kafetzopoulos and Gotzamani [82] and Prajogo et al. [83]. The existence of the common method variance or bias was examined, and the results show that the common method variance is not a problem in this research (in the factor analysis of the main components, no factor explains most of the variance).

\subsection{Data Analysis}

The data analysis was performed with SPSS 19.0 (Statistical Package for the Social Sciences, Chicago, EE.UU.), in the case of scale validation through an Exploratory Factor Analysis (EFA) program and AMOS Version 20.0 (Analysis of Moment Structures) that allows the estimation and contrast of structural models (scale validation and estimation of the SEM model).

\subsubsection{Validation of the Measurement Model}

To validate the measurement models of the four constructs (internal motivations, external motivations, barriers and benefits) considered, the psychometric properties of the scales are analyzed in order to test whether the items set forth in the questionnaire have properly measured the constructs [84]: reliability, one-dimensionality and validity. This process is developed in two phases: one of an exploratory nature through exploratory factorial analysis and the other in which a first order factorial analysis will be performed, further depurating the observable variables and keeping those that better represent the latent concept.

In order to calculate the reliability, the internal consistency method or Kuder-Richardson method was used. The following analyses were carried out: the calculation of the correlation coefficients of the Pearson item-total (the correlation between the items should exceed 0.3 according to Nunnally [85]); 
and Cronbach's alpha must be greater than 0.7 [85] or 0.8 for confirmatory studies. With this process, we limit the number of items that will measure each concept.

An Exploratory Factor Analysis (EFA) with varimax rotation was performed to identify the dimensionality of the scales [86]. This analysis allows one to identify the underlying dimensions in each of the constructs, by sharing the variance amongst the different factors. Prior to this analysis, we found that the data are suitable for the application of this technique: the correlation matrix is examined to verify among all of the available variables that there is a significant number of high correlations (>0.5); Bartlett's test of sphericity (estimate of the $\chi^{2}$ test, significance level below 0.05) was performed; and the Kaiser-Meyer-Olkin index and Measure of Simple Adequacy (MSA) is acceptable for values below 0.5 .

As the second phase of the scales' depuration process, the factorial solutions are subjected to validation through confirmatory factor analysis, which allows one to test the quality adjustment of the proposed solution (the quality adjustment of the model of structural measure and the global adjustment of the model are evaluated), which ensures the validity and reliability of the measurement scales by further depurating them if necessary. This technique analyzes reliability, validity and one-dimensionality [87] again. To examine the adjustment of the structural measurement model, the significance of the estimated coefficients according to the following parameters is taken into account: the critical coefficient of each standardized indicator should exceed \pm 1.96 ; the standard regression weight should be approximately 0.7 , some authors place the minimum level at $0.5[88,89]$.

After eliminating critical causal relationships whose coefficients are not significant, if necessary, we proceed to re-specify the model by studying the modification indexes' potential relationships and waste matrices. The internal validity of the measurement model is evaluated by calculating the Compound Reliability (CR), which must have a greater value than 0.6 [90] and through the extracted average variance (AVE) be equal to or greater than 0.5 [87].

The global adjustment of the measurement models is made taking into account the following measurement indices: chi-square $\left(\chi^{2}\right)$; Comparative Fit Index (CFI); Goodness of Fit Index (GFI); Normed Fit Index (NFI); Adjusted Goodness of Fit Index (AGFI); Robustness of Mean Squared Error Approximation (RMSEA). Recommended values greater than 0.9, according to Hair et al. [87], for the CFI, GFI, NFI and AGFI indices and for RMSEA, values below 0.08 [91] are recommended and to ideally lie between 0.05 and 0.08 .

\subsubsection{Estimation of Structural Equation Modeling}

The proposed global model, which includes the hypotheses to be tested, is estimated by applying the Structural Equation Modeling (SEM)-maximum likelihood method. This technique also provides the structure of causal relationships, as well as the importance of the effect of each of the constructs on the benefits. To examine the structural measurement model adjustment, first the significance is taken into account (standard regression weight) where the critical coefficient must exceed \pm 1.96 . Secondly, the indices of the goodness of fit of the model [89] are taken into account (CFI, GFI, NFI, AGFI indices and RMSEA). The measure of $\mathrm{R}^{2}$ indicates the amount of variance of the construct that is explained by the model.

\section{Results}

\subsection{Measurement Model}

The mean value, standard deviation, factor loading and reliabilities for each measurement statement and construct are shown in Table 1. $\alpha$ Cronbach is higher than 0.7 in all cases, so its reliability can be considered satisfactory. The factor analysis of principal components did not involve the removal of any items; in all cases, the factor loadings are greater than 0.5 [87], and the cumulative percentage of explained variance is higher than $50 \%$ in all of the scales. 
Table 1. Descriptive findings and exploratory factor analysis (reliability and validity of scales).

\begin{tabular}{|c|c|c|c|c|c|}
\hline \multirow[b]{2}{*}{ Constructs Included SEM } & \multirow[b]{2}{*}{ Scale Items ${ }^{A}$} & \multirow[b]{2}{*}{ Mean } & \multirow[b]{2}{*}{ (s.d.) ${ }^{B}$} & \multicolumn{2}{|r|}{ Exploratory Factor Analysis } \\
\hline & & & & Loadings & $\begin{array}{c}\text { Bartlett's Test of Sphericity } \\
\text { Kaiser-Meyer-Olkin Index (KMO) }\end{array}$ \\
\hline \multicolumn{6}{|c|}{ Motivation: It is not one-dimensional, but is formed by two factors, external and internal motivations } \\
\hline \multicolumn{6}{|l|}{ External Motivation } \\
\hline By customers' requirements & MO1 & 2.43 & 1.23 & 0.826 & \multirow{8}{*}{$\begin{array}{c}\chi^{2}\left(\text { sig. }{ }^{C}\right): 198.992(0.000) \\
\text { df: } 15 \\
\text { KMO: } 0.606 \\
\text { Measure of simple adequacy: (0.599-0.722) } \\
\alpha \text { Cronbach (External motivation): } 0.709 \\
\alpha \text { Cronbach (Internal motivation): } 0.752 \\
\text { \% Variance (External motivation): } 33.85 \\
\text { \% Variance (Internal motivation): } 32.61 \\
\text { Cumulative \% variance: } 66.46\end{array}$} \\
\hline By providers/suppliers' requirements & $\mathrm{MO} 2$ & 2.00 & 0.98 & 0.857 & \\
\hline The competition has an Environmental Management System & MO3 & 2.48 & 1.35 & 0.723 & \\
\hline Internal Motivation & & & & & \\
\hline Integrating Environment into corporate strategy & $\mathrm{MO} 4$ & 4.03 & 1.07 & 0.880 & \\
\hline Maintain socially-responsible behavior & MO5 & 4.33 & 0.87 & 0.891 & \\
\hline It was a strategic decision of the organization & MO6 & 4.28 & 0.90 & 0.670 & \\
\hline & & & & & \\
\hline \multicolumn{6}{|l|}{ Barriers } \\
\hline & & & & & $\chi^{2}$ (sig.): $193.197(0.000)$ \\
\hline Lack of human and material resources & BA1 & 2.78 & 1.10 & 0.684 & df: 6 \\
\hline Lack of staff involvement, difficulties involving and motivating internal staff & BA2 & 2.94 & 1.26 & 0.865 & KMO: 0.763 \\
\hline Lack of top management commitment & BA3 & 2.09 & 1.19 & 0.805 & Measure of simple adequacy: $(0.831-0.713)$ \\
\hline Little concern of the company for issues related to environmental management & BA4 & 2.19 & 1.26 & 0.901 & $\alpha$ Cronbach: 0.834 \\
\hline & & & & & \% Variance: 66.89 \\
\hline \multicolumn{6}{|l|}{ Benefits } \\
\hline Improvement in relationships with consumers and increase in consumer & B1 & 3.49 & 1.21 & 0.666 & \multirow{8}{*}{$\begin{array}{l}\chi^{2} \text { (sig.): } 362.032(0.000) \\
\text { df: } 21 \\
\text { KMO: } 0.874 \\
\text { re of simple adequacy: }(0.929-0.881) \\
\text { } \text { Cronbach: } 0.871 \\
\text { \% Variance: } 56.91\end{array}$} \\
\hline confidence and satisfaction & B2 & 3.43 & 1.11 & 0.659 & \\
\hline Cost savings in the medium and long term & B3 & 3.11 & 1.18 & 0.859 & \\
\hline Improved productivity & $\begin{array}{l}\text { D3 } \\
\text { B4 }\end{array}$ & 3.09 & 1.18 & 0.853 & \\
\hline Improved business profitability & $\begin{array}{l}\text { B4 } \\
\text { B5 }\end{array}$ & 3.55 & 1.16 & 0.766 & \\
\hline Improved relationships with public administrations & B5 & & 1.15 & 0.781 & \\
\hline It helps to improve internal management of the organization & $\begin{array}{l}\text { B6 } \\
\text { B7 }\end{array}$ & 3.04 & 1.09 & 0.781 & \\
\hline Improves providers'/suppliers' relationships & & & & & \\
\hline
\end{tabular}


In the case of the motivation scale, taking into account previous literature [41], it has been considered to be divided into two different constructs (internal and external motivation). In order to support empirically that decision, factor analysis on the motivations (considering all items) was conducted. The results show that the motivation construct is not one-dimensional. In order to prove that the construct motivation is not comprised of two critical dimensions, but two different constructs, we developed a strategy of rival models, proposing a factorial model of first order in which the various dimensions are not differentiated and another one where they differ. The most appropriate one is where the two critical dimensions are differentiated. Below, we propose a second order model that allowed us to confirm that there are two critical dimensions.

To finish, we analyze the reliability and validity of the scales again: average variance must take a value greater than 0.5 and composite reliability a minimum value of 0.7 . Therefore, the internal validity of the measurement models is adequate. Content validity is supported by the literature review, and the validity of the concept is measured through convergent validity (optimal values critical factor $> \pm 1.96$, $\beta>0.5$ ) (Table 2). It can be seen that the minimum required is met.

Table 2. Reliability and confirmatory factor analysis. AGFI, Adjusted Goodness of Fit Index; CFI, Comparative Fit Index; RMSEA, Robustness of Mean Squared Error Approximation.

\begin{tabular}{|c|c|c|c|c|}
\hline Scales $^{\text {a }}$ & $\beta$ & CR & AVE & Confirmatory Factor Analysis \\
\hline \multicolumn{5}{|l|}{ External Motivations $(\alpha=0.709)$} \\
\hline By providers/suppliers' requirement & 0.977 & 0.71 & 0.57 & \multirow{4}{*}{$\begin{array}{c}\chi^{2}(\mathrm{df})=5.579(p=0.233) \\
\mathrm{GFI}=0.981, \mathrm{AGFI}=0.929 \\
\mathrm{CFI}=0.990, \mathrm{RMSEA}=0.059 \\
\chi^{2} \text { normalized }\left(\chi^{2} / \mathrm{df}\right)=1.595\end{array}$} \\
\hline Internal Motivations ( $\alpha=0.752)$ & & & & \\
\hline Maintain socially-responsible behavior & 0.872 & \multirow[t]{2}{*}{0.80} & \multirow[t]{2}{*}{0.59} & \\
\hline It was a strategic decision of the organization & 0.647 * & & & \\
\hline \multicolumn{5}{|l|}{ Barriers $(\alpha=0.834)$} \\
\hline Lack of human and material resources & 0.541 & \multirow[b]{2}{*}{0.79} & \multirow[b]{2}{*}{0.49} & \multirow{2}{*}{$\begin{array}{c}\chi^{2}(\mathrm{df})=5.720(p=0.57) \\
\mathrm{GFI}=0.975, \mathrm{AGFI}=0.875 \\
\mathrm{CFI}=0.981, \mathrm{RMSEA}=0.128 \\
\chi^{2} \text { normalized }\left(\chi^{2} / \mathrm{df}\right)=2.860\end{array}$} \\
\hline $\begin{array}{l}\text { Lack of staff involvement, difficulties involving and motivating } \\
\text { internal staff }\end{array}$ & 0.782 & & & \\
\hline \multicolumn{5}{|l|}{ Benefits $(\alpha=0.871)$} \\
\hline $\begin{array}{l}\text { Improvement in relationships with consumers and increase in } \\
\text { consumer confidence and satisfaction }\end{array}$ & 0.537 & \multirow{5}{*}{0.77} & \multirow{5}{*}{0.52} & \multirow{5}{*}{$\begin{array}{c}\chi^{2}(\mathrm{df})=7.534(p=0.184), \\
\mathrm{GFI}=0.975, \text { AGFI }=0.926, \\
\text { CFI }=0.989, \text { RMSEA }=0.067 \\
\chi^{2} \text { normalized }\left(\chi^{2} / \mathrm{df}\right)=1.507\end{array}$} \\
\hline Cost savings in medium and long-term & 0.587 & & & \\
\hline Improved productivity & 0.901 & & & \\
\hline Improved business profitability & 0.895 & & & \\
\hline Improved relationships with public administrations & 0.697 & & & \\
\hline
\end{tabular}

a All significant at $p$-value $<0.001$, except ${ }^{*}$ significant at $p$-value $<0.05 ; \beta$ : standard regression weight; $\alpha$ reliability (Cronbach's $\alpha$ ); CR: Composite Reliability; AV: Average Variance Extracted. Source: authors' own data.

Discriminant validity, which verifies that each factor represents a separate dimension, was analyzed (Table 3): (1) using the approach in which discriminant validation is confirmed if the Cronbach's alpha of each scale is higher than any of the correlations between that scale and the rest, which was proven; and (2) examining whether inter-factor correlations are less than the square root of the average variance extracted [92]. 
Table 3. Correlation matrix and discriminant validity.

\begin{tabular}{ccccccc}
\hline & AVE & (1) & (2) & (3) & (4) \\
\hline External motivations & 0.57 & \multirow{2}{*}{${ }^{c} 0.019,(0.087-0.369)$} & $0.709^{\mathrm{a}}$ & & & \\
\cline { 1 - 5 } Internal motivations & 0.71 & & $0.210^{*, \mathrm{~b}}$ & 0.871 & & \\
\hline Barriers & & 0.49 & 0.535 & 0.440 & 0.834 & \\
\hline Benefits & & 0.52 & $-0.146^{*}$ & $0.237^{*}$ & $-0.185^{*}$ & 0.871 \\
\hline
\end{tabular}

a Shown in bold on the main diagonal are the Cronbach's alpha for each scale, which should be higher than the correlation between that scale and the rest; ${ }^{b}$ inter-scale correlation; ${ }^{c}$ the squared correlation between pairs of factors (less than AVE) and confidence interval for the estimated correlations, \pm twice the standard error, does not include the value of 1 ; all significant at $p$-value $<0.001$, except ${ }^{*}$ significant at $p$-value $<0.05$. Source: authors' own data.

\subsection{Hypothesis Testing}

The results indicate that the quality adjustment of the model that relates the internal, external motivations and barriers with benefits is adequate; all indices (Figure 2) are within acceptable limits and exceed minimum values recommended in the literature $[87,89]$.

All hypotheses proposed are statistically supported by significant standardized coefficients $(\beta)$. In Figure 2, they appear together with the hypotheses and indicate the weights of the direct effects of one variable on another and the direction. They are all significant at level $p<0.05$ or at $p<001$.

The $\mathrm{R}^{2}$ measure that appears next to the constructs indicates the amount of variance that is explained by the model. The proposed model (motivations and barriers) explains $55.5 \%$ of the benefits $\left(R^{2}=0.555\right.$, may be considered acceptable).

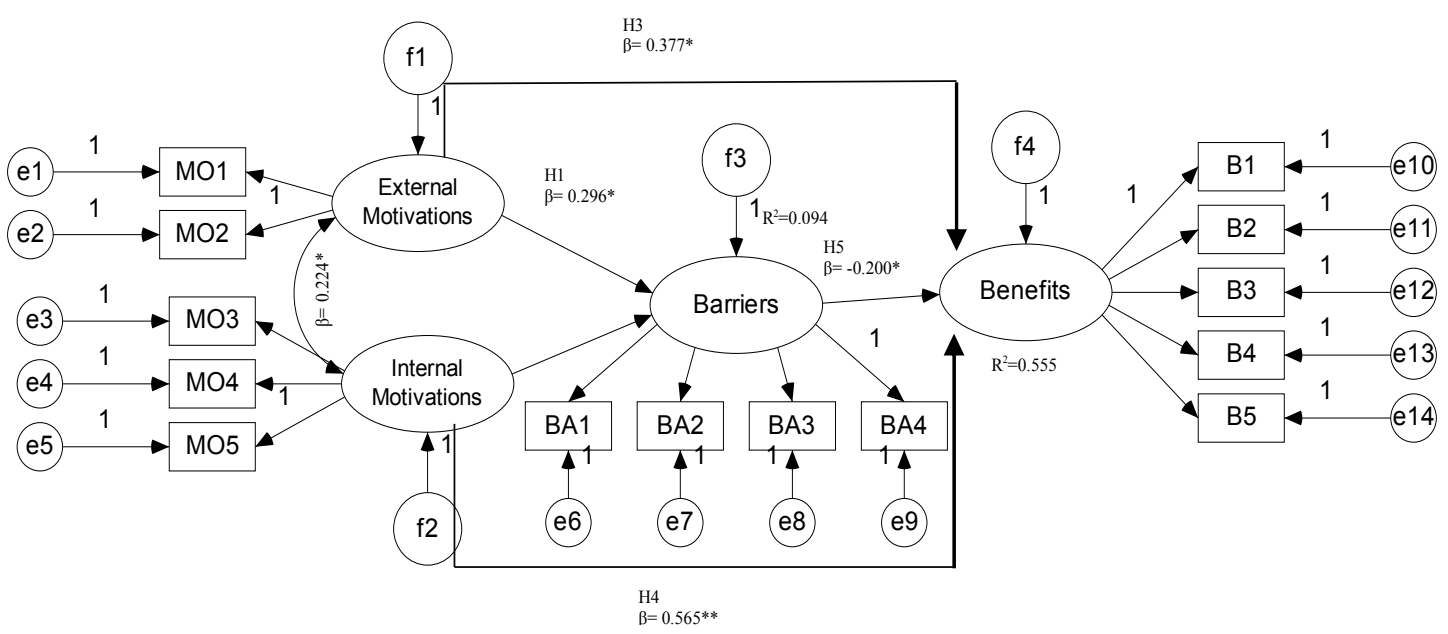

Figure 2. Diagram of the final structural model. ${ }^{*} p<0.05 ;{ }^{*} p<0.001 ; \chi^{2}(\mathrm{df6})=93.059(p=0.041)$, $\mathrm{GFI}=0.897, \mathrm{AGFI}=0.848, \mathrm{CFI}=0.966, \mathrm{RMSEA}=0.052, \chi^{2}$ normalized $\left(\chi^{2} / \mathrm{df}\right)=1.311$; measurement errors: $\mathrm{e} 1, \ldots, \mathrm{e} 14, \mathrm{f1}, \ldots$, f4; source: authors' own data.

Finally, the direct effects of each construct on the barriers and benefits and the indirect and total effects are also tested (Table 4). It can be observed that the three variables considered have a direct effect on benefits and indirect effects through barriers that are insignificant. The effect of the barriers on benefits is very small, but it does exist. 
Table 4. Direct, indirect and total effects on benefits.

\begin{tabular}{|c|c|c|c|c|c|}
\hline & nstructs & Effects & Internal Motivations & External Motivations & Barriers \\
\hline \multirow{3}{*}{1} & \multirow{3}{*}{ Barriers } & Direct & -0.170 & 0.296 & - \\
\hline & & Indirect & - & - & - \\
\hline & & Total & -0.170 & 0.296 & - \\
\hline \multirow{3}{*}{2} & \multirow{3}{*}{ Benefits } & Direct & 0.565 & 0.377 & -0.200 \\
\hline & & Indirect & 0.059 & -0.034 & - \\
\hline & & Total & 0.624 & 0.343 & -0.200 \\
\hline
\end{tabular}

Source: authors' own data.

\section{Discussion}

Before beginning the discussion of the results obtained, we want to verify by comparing the results obtained with other studies, and since there have been very few done in companies with EMSs, they are also compared with studies of companies that have implemented a quality management system, which are much more numerous. For the use of both types of studies conducted in companies with two different standards (ISO 9001 and ISO 14001 or EMAS), what was stated by Corbett [93] and Marimon et al. [94] is taken into account, which indicates the similarity of both standards. Due to the similarity in structure, for the design of the ISO 14001, the ISO $9001[27,35]$ is used as a reference, as well as in the process of diffusion. In the same vein, there have been studies such as Boiral and Roy [95], Jang and Ling [96] and Nair and Prajogo [97] analyzing the similarity of both standards concluding that they are implemented in organizations following the same pattern, regarding the level of integration, internalization and depth of their management systems.

The H1 hypothesis proposes that greater external motivation from the company reduces the level of perceived barriers encountered in the implementation of EMSs. The proposed hypothesis is not corroborated $(\beta=0.296, t=2.373, p<0.05)$, in the sense that we had proposed a negative relationship and a positive and significant relationship was observed. This means that when the external motivation goes up by one standard deviation, the barriers go up by 0.296 standard deviations. Therefore, the data show that when companies decide to implement EMSs due to customers' requirements and providers' / suppliers' requirements, the perception of the barriers encountered is not reduced. We think this may be because companies implement the system responding to market requirements; they do not focus their efforts on the design of the management system to meet the internal needs (continuous improvement process), such as in the case of internal motivations, and therefore, do not encourage to the same extent the interiorization of the rule on a day to day basis $[23,79,95,98]$; therefore, the perception of the barriers they have to face is not reduced. In this same line, Christmann and Taylor [21] and Heras-Saizarbitoria et al. [34] argue that external pressures can lead to a superficial adoption of an EMS, mostly to improve the image of the organization rather than its environmental performance.

The $\mathrm{H} 2$ hypothesis, which proposes that internal motivations reduce the perception of the barriers faced by the company in its process of implementing its EMS, is confirmed ( $\beta=-0.170, t=-2.762$, $p<0.05)$; the path of regression is negative.

The $\mathrm{H} 3$ and $\mathrm{H} 4$ hypotheses that assume a positive and significant relationship of both internal and external motivations with the benefits are confirmed $(\beta=0.565, t=4.073, p<001 ; \beta=0.377$, $t=2.841, p<0.05)$. The results are corroborated by the results obtained in studies by Fryxell et al. [99], Gavronski et al. [18] and Heras-Saizarbitoria et al. [34], which validated empirically the positive relationship with the benefits. It can also be observed that the internal motivations have a standardized coefficient $(\beta)$ higher than that of the external motivations, which means that external motivations have more influence on the benefits (improved consumer relationships and increased consumer confidence and satisfaction, cost savings in the medium and long term, improved productivity, improved business profitability and improved relationships with public administrations). This result is corroborated in the study by Heras-Saizarbitoria et al. [34], who found that the correlation and regression coefficients in the case of internal motivations are statistically significant and higher than the external motivations for 
four of the six benefits analyzed. They are also corroborated by other studies conducted in companies with ISO $9001[95,100-102]$ and ISO $14001[63,76,103]$ certification.

Finally, the barriers $(\beta=-0.200, t=-2.043, p<0.05)$ negatively impact benefits, which leads to the acceptance of H5. These results are corroborated by Subrahmanya and Rajashekhar [104], who found in their study that some barriers make implementation difficult, in this case a quality management system, so organizations have not achieved the expected benefits. In the implementation of EMSs as we can see in the results of the structural model proposed, the same would be expected, i.e., the higher the perceived barriers, the lower the level of implementation and, therefore, the lower the perceived benefits [96].

The determinants, external motivations, internal motivation and barriers explain $55.5 \%$ of the variance in benefits (Table 5).

Table 5. Structural model results.

\begin{tabular}{ccc}
\hline Constructs & $\boldsymbol{\beta}$ (Standard Regression Weight) & Hypotheses \\
\hline External Motivations $-\rightarrow$ Barriers & $0.296^{*}$ & H1 not corroborated \\
Internal Motivations $-\rightarrow$ Barriers & $-0.170^{*}$ & H2 corroborated \\
External Motivations $-\rightarrow$ Benefits & $0.377^{*}$ & H3 corroborated \\
Internal Motivations $-\rightarrow$ Benefits & $0.565^{* *}$ & H4 corroborated \\
Barriers $-\rightarrow$ Benefits & $-0.200^{*}$ & H5 corroborated \\
\hline
\end{tabular}

${ }^{*} p<0.05 ;{ }^{* *} p<0.001$. Source: authors' own data.

\section{Conclusions and Implications}

This study is novel because it aims to fill a gap existing in the literature. Until now, several studies have tried to identify the motivations that lead companies to implement an EMS based on the ISO 14001 or EMAS standard and the perceived barriers in its implementation $[11,18,26,37]$. Other studies identify the benefits derived from the implementation of these systems, such as Zutshi and Sohal [11], Gavronski et al. [18], Heras-Saizarbitoria et al. [34] and Martín-Peña et al. [26], and a large number of researchers analyzed how environmental practices influenced business performance $[8,58,67,105,106]$.

However, there is no study that intends to analyze the relationship between the motivations, barriers and benefits of implementing EMSs together. Tarí et al. [53] (p. 308) state that "a way of explaining better the effects of both standards (ISO 9001 and 14001) on performance is including variables related to motives for certification in future research studies", and in this research, they are considered. In addition, the results of this study allow us to respond to questions raised and studied in other qualitative research of an exploratory nature and that proposed that a quantitative research analysis would be interesting, as for example companies that implement EMSs motivated by internal reasons obtain higher benefits than those that are motivated by external reasons $[63,74,76]$.

Therefore, this research has several academic implications. The findings show that four of the five hypotheses are confirmed. The main contribution of this study is to verify that the motivations that lead companies to implement EMSs positively affect the benefits derived from the implementation, noting that the internal motivations have a stronger influence on the benefits (improved performance results, both internal and external performance) than the external motivations $[22,34,63,76,107]$. Generally, companies motivated to implement a quality management system to improve internal efficiency show a higher degree of the implementation of quality practices [108-110] and, therefore, greater benefits, and the same is considered in the case of environmental management practices. In the same vein, Tari et al. [53] (p. 308) state "that certification in itself leads to few benefits. However, when a firm really applies the quality system underlying the standard, and there is a real commitment to quality and to the environment, that is, when the standards are interiorized, there is an increased possibility of attaining the benefits listed, including the financial ones". 
On the other hand, motivations also affect the perceived barriers, and these influence the benefits negatively, i.e., the higher the barriers encountered, the lower the perceived benefits. It is also observed that internal motivations reduce the perception of the barriers they are faced with, and on the other hand, external motivations are influenced by increasing perception.

This study also has a number of managerial implications. Firstly, companies that want to implement an EMS should take into account that the motivations that drive them to start the process influence the perceived internal and external benefits; therefore, it is very important that when managers make the decision, it should be motivated by both, with the aim of achieving the highest possible benefits of the process (internal and external benefits). In this sense, they should bear in mind, taking into account the results of different studies, that implementing EMSs only to respond to market demand (suppliers and customers) leads to obtaining benefits related to improving the image of the organization [95]. On the other hand, implementing it due to internal motivations (in pursuit of improving the internal efficiency of the company) leads companies to obtain greater benefits $[63,74,76]$. In our study, we also observed that it is the internal motivations that are related to higher benefits.

Secondly, corporate managers must ensure that their level of motivation is adequate. In this sense, existing studies both at the professional level and of an exploratory empirical nature state that a greater motivation leads the company to experience greater benefits $[9,11,74,111]$. However, these studies analyzed separately motivations and benefits derived from the implementation and certification of an EMS; therefore, this research work is relevant because it analyzes them together and by using a quantitative analysis and allows corroborating the findings by other researchers.

Thirdly, managers must know and understand the barriers they will have to face during their implementation process, which will allow them, on the one hand, to anticipate and resolve problems that may arise and increase the chance of completing the implementation process of their EMS successfully, and on the other hand, by reducing them, they ensure achieving higher benefits, because as can be observed in this study, a relationship between barriers and benefits exists, although its influence is weak.

In short, the approach proposed in this research, to understand and analyze how the motivations, barriers and benefits are related is important, on the one hand, for companies that are already certified in an environmental management system and want to optimize the benefits derived from its implementation. The results allow them to see that through a change in their motivations (from external to internal or a mix of both), this will allow them to overcome more easily the barriers that remain after implementation, that prevent reaching a high level of efficiency in the system and, therefore, obtaining higher benefits. On the other hand, it is relevant for companies that want to start the implementation process, by knowing how the motivations that lead them to implement the system can affect the barriers that must be overcome and the benefits obtained and, thus, make the right decisions.

Finally, this study faced several limitations, as well. The first one is related to most of the research of this type; the field work was performed in a specific geographical region (Autonomous Community of Galicia-Spain), and the study results may be difficult to extrapolate to other countries. The generalization of the findings should be made with caution and always from a previous analysis of the characteristics of the population to consider. The second limitation is related to the use of cross-sectional data. To overcome this limitation, it would be necessary to carry out the study at different moments of time (longitudinal design).

As a future line of research, it would be interesting to study, as Gavronski et al. [18] did, if the internal motivations maintain a strong relationship with the internal benefits and external motivations with external benefits.

Author Contributions: All authors contributed equally to this work. All authors wrote, reviewed and commented on the manuscript. All authors have read and approved the final manuscript.

Conflicts of Interest: The authors declare no conflict of interest. 


\section{Appendix A}

Table A1. Questionnaire.

\begin{tabular}{l}
\hline Motivation: It Is Not One-Dimensional, But Is Formed by Two Factors, External and Internal Motivations \\
\hline External Motivation \\
\hline By customers' requirements \\
By providers/suppliers' requirements \\
The has an Environmental Management System competition \\
\hline Internal Motivation \\
\hline Integrating Environment into corporate strategy \\
Maintain socially-responsible behavior \\
It was a strategic decision of the organization \\
\hline \\
\hline Lack of human and material resources \\
Lack of staff involvement, difficulties to involve and motivate internal staff \\
Lack of top management commitment \\
Little concern of the company for issues related to environmental management \\
\hline \\
Improvement in relationships with consumers and increase in consumer confidence and satisfaction \\
Cost savings in the medium and long term \\
Improved productivity \\
Improved business profitability \\
Improved relationships with public administrations \\
It helps to improve internal management of the organization \\
Improves providers' / suppliers' relationships \\
\hline
\end{tabular}

\section{References}

1. Nunes, B.; Bennett, D. The contribution of modularity to green operations practices. Braz. J. Oper. Prod. Manag. 2010, 5, 93-108.

2. Kollman, K.; Prakash, A. Green by choice? Cross-national variations in firms' responses to EMS-based environmental regimes. World Politics 2001, 53, 399-430. [CrossRef]

3. EMAS III. Regulation (EC) No 1221/2009 of The European Parliament and of The Council. Available online: http:/ / eur-lex.europa.eu/legal-content/en/ALL/?uri=CELEX:32009R1221 (assessed on 30 September 2016).

4. Steger, U. Environmental management systems: Empirical evidence and further perspectives. Eur. Manag. J. 2000, 18, 23-37. [CrossRef]

5. Watson, M.; Emery, A.R. Law, economics and the environment: A comparative study of environmental management systems. Manag. Audit. J. 2004, 19, 760-773. [CrossRef]

6. European Commission. Reports and Statistics 2015. Available online: http://ec.europa.eu (accessed on 10 April 2016).

7. Potoski, M.; Prakash, A. Covenants with weak swords: ISO 14001 and facilities' environmental performance. J. Policy Anal. Manag. 2005, 24, 745-769. [CrossRef]

8. Link, S.; Naveh, E. Standardization and discretion: Does the environmental standard ISO 14001 lead to performance benefits? IEEE Trans. Eng. Manag. 2006, 53, 508-519. [CrossRef]

9. Pan, J.N. A comparative study on motivation for and experience with ISO 9000 and ISO 14000 certification among Far Eastern countries. Ind. Manag. Data Syst. 2003, 103, 564-578. [CrossRef]

10. Hillary, R. Environmental management systems and the smaller enterprise. J. Clean. Prod. 2004, 12, 561-569. [CrossRef]

11. Zutshi, A.; Sohal, A. Environmental management system adoption by Austalasian organisations: Part 1: Reasons, benefits and impediments. Technovation 2004, 24, 335-357. [CrossRef]

12. Kumar, S. Resource use and waste management in Vietnam hotel industry. J. Clean. Prod. 2005, 13, $109-116$. 
13. Heras, I.; Arana, G. Impacto de la certificación ISO 14001 en el rendimiento financiero empresarial: Conclusiones de un estudio empírico. Cuad. Econ. Dir. Empresa 2011, 14, 112-122.

14. Quazi, H.A.; Khoo, Y.K.; Tan, C.M.; Wong, P.S. Motivation for ISO 14000 certification: Development of a predictive model. Int. J. Manag. Sci. 2001, 29, 525-542. [CrossRef]

15. Yiridoe, E.K.; Clark, J.S.; Marett, G.E.; Gordon, R.; Duinker, P. ISO 14001 EMS standard registration decisions among Canadian organizations. Agribusiness 2003, 19, 439-457. [CrossRef]

16. González-Benito, J.; González-Benito, O. An analysis of the relationship between environmental motivations and ISO14001 certification. Br. J. Manag. 2005, 16, 133-148. [CrossRef]

17. Schylander, E.; Martinuzzi, A. ISO 14001-Experiences, effects and future challenges: A national study in Austria. Bus. Strategy Environ. 2007, 16, 133-147. [CrossRef]

18. Gavronski, I.; Ferrer, G.; Paiva, E.L. ISO 14001 certification in Brazil: Motivations and benefits. J. Clean. Prod. 2008, 16, 87-94. [CrossRef]

19. Mariotti, F.; Kadasah, N.; Abdulghaffar, N. Motivations and barriers affecting the implementation of ISO 14001 in Saudi Arabia: An empirical investigation. Total Q. Manag. Bus. Excell. 2014, 25, 1352-1364. [CrossRef]

20. Jiang, R.J.; Bansal, P. Seeing the need for ISO 14001. J. Manag. Stud. 2003, 40, 1047-1067. [CrossRef]

21. Christmann, P.; Taylor, G. Firm self-regulation through international certifiable standards: Determinants of symbolic versus substantive implementation. J. Int. Bus. Stud. 2006, 37, 863-878. [CrossRef]

22. Boiral, O. Corporate greening through ISO 14001: A rational myth? Org. Sci. 2007, 18, 127-146. [CrossRef]

23. Boiral, O. Managing with ISO systems: Lessons from practice. Long Range Plan. 2011, 44, 197-220. [CrossRef]

24. Montabon, F.; Melnyk, S.A.; Sroufe, R.; Calantone, R.J. ISO 14000: Assessing its perceived impact on corporate performance. J. Supply Chain Manag. 2000, 36, 4-16. [CrossRef]

25. Poksinska, B.; Jörn Dahlgaard, J.; Eklund, J.A. Implementing ISO 14000 in Sweden: Motives, benefits and comparisons with ISO 9000. Int. J. Q. Reliab. Manag. 2003, 20, 585-606. [CrossRef]

26. Martín-Peña, M.L.; Díaz-Garrido, E.; Sánchez-López, J.M. Analysis of benefits and difficulties associated with firms' Environmental Management Systems: The case of the Spanish automotive industry. J. Clean. Prod. 2014, 70, 220-230. [CrossRef]

27. Boiral, O. Du Developpement Durable Aux Normes ISO: Peaut-on Certifier La-Bonne Conduite-Des Entreprises. McGill Int'l J. Sust. Dev. L. Pol'y 2006, 2, 91.

28. Johnstone, N.; Scapecchi, P.; Ytterhus, B.; Wolff, R. The firm, environmental management and environmental measures: Lessons from a survey of European manufacturing firms. J. Environ. Plan. Manag. 2004, 47, 685-707. [CrossRef]

29. Kolln, K.; Prakash, A. EMS-based environmental regimes as club goods: Examining variations in firm-level adoption of ISO 14001 and EMAS in UK, US and Germany. Policy Sci. 2002, 35, 43-67. [CrossRef]

30. Melnyk, S.A.; Sroufe, R.P.; Calantone, R.L. Assessing the effectiveness of US voluntary environmental programmes: an empirical study. Int. J. Prod. Res. 2002, 40, 1853-1878. [CrossRef]

31. Wernerfelt, B. A resource-based view of the firm. Strateg. Manag. J. 1984, 5, 171-180. [CrossRef]

32. Prajogo, D.I. The roles of firms' motives in affecting the outcomes of ISO 9000 adoption. Int. J. Oper. Prod. Manag. 2011, 31, 78-100. [CrossRef]

33. Takahashi, T.; Nakamura, M. The impact of operational characteristics on firms' EMS decisions: Strategic adoption of ISO 14001 certifications. Corp. Soc. Responsib. Environ. Manag. 2012, 17, 215-229. [CrossRef]

34. Heras-Saizarbitoria, I.; Arana, G.; Molina-Azorín, J.F. Do drivers matter for the benefits of ISO 14001? Int. J. Oper. Manag. 2011, 31, 192-215. [CrossRef]

35. Fryxell, G.E.; Szeto, A. The influence of motivations for seeking ISO 14001 certification: An empirical study of ISO 14001 certified facilities in Hong Kong. J. Environ. Manag. 2002, 65, 223-238. [CrossRef]

36. Zeng, S.X.; Tam, C.M.; Tam, V.W.; Deng, Z.M. Towards implementation of ISO 14001 environmental management systems in selected industries in China. J. Clean. Prod. 2005, 13, 645-656. [CrossRef]

37. Salomone, R. Integrated management systems: Experiences in Italian organizations. J. Clean. Prod. 2008, 16, 1786-1806. [CrossRef]

38. Umweltbendesamt. EMAS in Germany, Systematic Environmental Management: Report on Experience 1995 to 1998; Federal Environmental Agency: Berlin, Germany, 2000.

39. Morrow, D.; Rondinelli, D. Adopting Corporate Environmental Management Systems: Motivations and Results of ISO 14001 and EMAS Certification. Eur. Manag. J. 2002, 20, 159-171. [CrossRef] 
40. Bansal, P.; Roth, K. Why companies go green: A model of ecological responsiveness. Acad. Manag. J. 2000, 43, 717-736. [CrossRef]

41. Neumayer, E.; Perkins, R. Uneven geographies of organizational practice: Explaining the cross-national transfer and adoption of ISO 9000. Econ. Geogr. 2005, 81, 237-259. [CrossRef]

42. Post, J.E.; Altma, B.W. Managing the environmental change process: Barriers and opportunities. J. Org. Chang. Manag. 1994, 7, 64-81. [CrossRef]

43. Zilahy, G. Organisational factors determining the implementation of cleaner production measures in the corporate sector. J. Clean. Prod. 2004, 12, 311-319. [CrossRef]

44. Chavan, M. An appraisal of environment management systems: A competitive advantage for small businesses. Manag. Environ. Q. Int. J. 2005, 16, 444-463. [CrossRef]

45. Quazi, H.A. Implementation of an environmental management system: The experience of companies operating in Singapore. Ind. Manag. Data Syst. 1999, 99, 302-311. [CrossRef]

46. Del Brío, J.; Fernández, E.; Junquera, B.; José Vázquez, C. Environmental managers and departments as driving forces of TQEM in Spanish industrial companies. Int. J. Q. Reliab. Manag. 2001, 18, 495-511. [CrossRef]

47. Johannson, L. The challenge of implementing ISO 14001 for small and medium-sized enterprises-Surviving in the new global jungle. Environ. Q. Manag. 1997, 7, 9-19. [CrossRef]

48. Masters, R.J. Overcoming the barriers to TQM's success. Q. Prog. 1996, 29, 53-55.

49. Walley, N.; Whitehead, B. It's not easy being green. Harv. Bus. Rev. 1994, 36, 46-52.

50. Van der Veldt, D. Case studies of ISO 14001: A new business guide for global environmental protection. Environ. Q. Manag. 1997, 7, 1-19. [CrossRef]

51. Cascio, J. International Environmental Management Standards. In Proceedings of the 1994 IEEE International Symposium on Electronics and the Environment, San Francisco, CA, USA, 2-4 May 1994; pp. 44-49.

52. Turk, A.M. The benefits associated with ISO 14001 certification for construction firms: Turkish case. J. Clean. Prod. 2009, 17, 559-569. [CrossRef]

53. Tarí, J.J.; Molina-Azorín, J.F.; Heras, I. Benefits of the ISO 9001 and ISO 14001 standards: A literature review. J. Ind. Eng. Manag. 2012, 5, 297-322. [CrossRef]

54. Heras, I.; Arana, G.; Díaz de Junguitu, A.; Espí, M.T.; Molina, J.F. Los Sistemas de Gestión Medioambiental y la Competitividad de las Empresas de la CAPV; Instituto Vasco de Competitividad: Bilbao, Spain, 2008.

55. Claver-Cortés, E.; Molina-Azorín, J.F.; Tarí, J.J.; López-Gamero, M.D. Enviromental management, quality management and firm performance: A review of empirical studies. In Corporate Enviromental Strategy and Competitive Advantage; Sharma, S., Aragón-Correa, J.A., Eds.; Edward Elgar: Cheltenham, UK, 2005; pp. 157-182.

56. Molina-Azorín, J.F.; Tarí, J.J.; Claver-Cortés, E.; López-Gamero, M.D. Quality management, environmental management and firm performance: A review of empirical studies and issues of integration. Int. J. Manag. Rev. 2009, 11, 197-222. [CrossRef]

57. Fisher, R.M. Applying ISO 14001 as a business tool for campus sustainability: A case study from New Zealand. Int. J. Sustain. High. Educ. 2003, 4, 138-150. [CrossRef]

58. Melnyk, S.A.; Sroufe, R.P.; Calantone, R. Assessing the impact of environmental management systems on corporate and environmental performance. J. Oper. Manag. 2003, 21, 329-351. [CrossRef]

59. Bansal, P.; Bogner, W. Deciding on ISO 14001: Economics, institutions, and context. Long Range Plan. 2002, 35, 269-290. [CrossRef]

60. Arena, M.; Azzone, G.; Platti, M. ISO14001: Motivations and benefits in the Italian metal industry. Int. J. Eng. Bus. Manag. 2012, 4. [CrossRef]

61. Chin, K.S. Factors influencing ISO 14000 implementation in printed circuit board manufacturing industry in Hong Kong. J. Environ. Plan. Manag. 1999, 42, 123-134. [CrossRef]

62. Psomas, E.L.; Fotopoulos, C.V.; Kafetzopoulos, D.P. Motives, difficulties and benefits in implementing the ISO 14001 Environmental Management System. Manag. Environ. Q. Int. J. 2011, 22, 502-521. [CrossRef]

63. Rondinelli, D.; Vastag, G. Panacea, common sense, or just a label?: The value of ISO 14001 environmental management systems. Eur. Manag. J. 2000, 18, 499-510. [CrossRef]

64. Russo, M.; Harrison, A. An empirical study of the impact of ISO 14001 registration on emissions performance. In Proceedings of the Ninth Greening of Industry Network Annual Conference, Bangkok, Thailand, 21-25 January 2000. 
65. King, A.A.; Lenox, M.J. Who Adopts Management Standards Early? An Examination of ISO 14001 Certifications. Available online: http://proceedings.aom.org/content/2001/1/A1.19 (assessed on 30 September 2016).

66. Tan, L.P. Implementing ISO 14001: Is it beneficial for firms in newly industrialized Malaysia? J. Clean. Prod. 2005, 13, 397-404. [CrossRef]

67. Wagner, M.; Van Phu, N.; Azomahou, T.; Wehrmeyer, W. The relationship between the environmental and economic performance of firms: An empirical analysis of the European paper industry. Corp. Soc. Responsib. Environ. Manag. 2002, 9, 133-146. [CrossRef]

68. Wahba, H. Does the market value corporate environmental responsibility? An empirical examination. Corp. Soc. Responsib. Environ. Manag. 2008, 15, 89-99. [CrossRef]

69. Prajogo, D.I.; McDermott, C.M. The relationship between total quality management practices and organizational culture. Int. J. Oper. Prod. Manag. 2005, 25, 1101-1122. [CrossRef]

70. Naor, M.; Goldstein, S.M.; Linderman, K.W.; Schroeder, R.G. The role of culture as driver of quality management and performance: Infrastructure versus core quality practices. Decis. Sci. 2008, 39, 671-702. [CrossRef]

71. Zu, X.; Robbins, T.L.; Fredendall, L.D. Mapping the critical links between organizational culture and TQM/Six Sigma practices. Int. J. Prod. Econ. 2010, 123, 86-106. [CrossRef]

72. Al-Jalahma, R. Impact of Organization Culture on TQM Implementation Barriers. Ph.D. Thesis, Brunel University, Uxbridge, UK, 2012.

73. Al-Khalifa, K.N.; Aspinwall, E.M. Using the competing values framework to investigate the culture of Qatar industries. Total Q. Manag. 2001, 12, 417-428. [CrossRef]

74. Hillary, R. (Ed.) Small and Medium-Sized Enterprises and the Environment: Business Imperatives; Greenleaf Publishing: Saltaire, UK, 2000.

75. Darnall, N.; Gallagher, D.R.; Andrews, R.; Amaral, D. Environmental management systems: Opportunities for improved environmental and business strategy. Environ. Q. Manag. 2000, 9, 1-9.

76. Kitazawa, S.; Sarkis, J. The relationship between ISO 14001 and continuous source reduction programs. Int. J. Oper. Prod. Manag. 2000, 20, 225-248. [CrossRef]

77. Nawrocka, D.; Parker, T. Finding the connection: Environmental management systems and environmental performance. J. Clean. Prod. 2009, 17, 601-607. [CrossRef]

78. Chan, E.S.; Wong, S.C. Motivations for ISO 14001 in the hotel industry. Tour. Manag. 2006, 27, 481-492. [CrossRef]

79. Yin, H.; Schmeidler, P.J. Why do standardized ISO 14001 environmental management systems lead to heterogeneous environmental outcomes? Bus. Strategy Environ. 2009, 18, 469-486. [CrossRef]

80. Podsakoff, P.M.; Organ, D.W. Self-reports in organizational research: Problems and prospects. J. Manag. 1986, 12, 531-544. [CrossRef]

81. Psomas, E.L.; Kafetzopoulos, D.P.; Fotopoulos, C.V. Developing and validating a measurement instrument of ISO 9001 effectiveness in food manufacturing SMEs. J. Manuf. Technol. Manag. 2012, 24, 52-77. [CrossRef]

82. Kafetzopoulos, D.P.; Gotzamani, K.D. Critical factors, food quality management and organizational performance. Food Control 2014, 40, 1-11. [CrossRef]

83. Prajogo, D.; Tang, A.; Lai, K.H. The diffusion of environmental management system and its effect on environmental management practices. Int. J. Oper. Prod. Manag. 2014, 34, 565-585. [CrossRef]

84. Anderson, J.C.; Gerbing, D.W. Structural Equation Modeling in Practice: A Review and Recommended Two-Step Approach. Psychol. Bull. 1988, 103, 411-423. [CrossRef]

85. Nunnally, J.C. Psychometric Theory; McGraw-Hill: New York, NY, USA, 1978.

86. Bagozzi, R.Y.B.; Baumgartner, P.J.H. The Evaluation of Structural Equation Models and Hypothesis Testing; Bagozzi, R., Ed.; Principles of Marketing Research; Backwell Publisher: Cambridge, UK, 1994; pp. 386-419.

87. Hair, J.F.; Anderson, R.E.; Tatham, R.L.; Black, W.C. Multivariate Data Analysis, 5th ed.; Prentice Hall: Upper Saddle River, NJ, USA, 1999.

88. Hildebrandt, L. Consumer retail satisfaction in rural areas: A reanalysis of survey data. J. Econ. Psychol. 1987, 8, 19-42. [CrossRef]

89. Jöreskog, K.G.; Sörbom, D. LISREL 8: Structural Equation Modeling with the SIMPLIS Command Language; Scientific Software International: Skokie, IL, USA, 1993. 
90. Bagozzi, R.P.; Yi, Y. On the evaluation of structural equation models. J. Acad. Mark. Sci. 1998, 16, 74-94. [CrossRef]

91. Steiger, J.H. Structural model evaluation and modification: An interval estimation approach. Multivar. Behav. Res. 1990, 25, 173-180. [CrossRef] [PubMed]

92. Fornell, C.; Larcker, D.F. Structural equation models with unobservable variables and measurement error: Algebra and statistics. J. Mark. Res. 1981, 18, 382-388. [CrossRef]

93. Corbett, C.J. Global diffusion of ISO 9000 certification through supply chains. Manuf. Serv. Oper. Manag. 2006, 8, 330-350. [CrossRef]

94. Marimon, F.; Casadesús, M.; Heras, I. ISO 9000 and ISO 14000 standards: An international diffusion model. Int. J. Oper. Prod. Manag. 2006, 26, 141-165. [CrossRef]

95. Boiral, O.; Roy, M.J. ISO 9000: Integration rationales and organizational impacts. Int. J. Oper. Prod. Manag. 2007, 27, 226-247. [CrossRef]

96. Jang, W.Y.; Lin, C.I. An integrated framework for ISO 9000 motivation, depth of ISO implementation and firm performance: The case of Taiwan. J. Manuf. Technol. Manag. 2008, 19, 194-216. [CrossRef]

97. Nair, A.; Prajogo, D. Internalisation of ISO 9000 standards: The antecedent role of functionalist and institutionalist drivers and performance implications. Int. J. Prod. Res. 2009, 47, 4545-4568. [CrossRef]

98. Perez, O.; Amichai-Hamburger, Y.; Shterental, T. The Dynamic of Corporate Self-Regulation: ISO 14001, Environmental Commitment, and Organizational Citizenship Behavior. Law Soc. Rev. 2009, 43, 593-630. [CrossRef]

99. Fryxell, G.E.; Lo, C.W.H.; Chung, S.S. Influence of motivations for seeking ISO 14001 certification on perceptions of EMS effectiveness in China. Environ. Manag. 2004, 33, 239-251. [CrossRef] [PubMed]

100. Lee, T.Y. The development of ISO 9000 certification and the future of quality management: A survey of certified firms in Hong Kong. Int. J. Q. Reliab. Manag. 1998, 15, 162-177. [CrossRef]

101. Jones, R.; Arndt, G.; Kustin, R. ISO 9000 among Australian companies: Impact of time and reasons for seeking certification on perceptions of benefits received. Int. J. Q. Reliab. Manag. 1997, 14, 650-660. [CrossRef]

102. Martínez-Costa, M.; Martínez-Lorente, A.R.; Choi, T.Y. Simultaneous consideration of TQM and ISO 9000 on performance and motivation: An empirical study of Spanish companies. Int. J. Prod. Econ. 2008, 113, $23-39$. [CrossRef]

103. Boiral, O.; Sala, J.M. Environmental management: Should industry adopt ISO 14001? Bus. Horiz. 1998, 41, 57-64. [CrossRef]

104. Subrahmanya Bhat, K.; Rajashekhar, J. An empirical study of barriers to TQM implementation in Indian industries. TQM J. 2009, 21, 261-272. [CrossRef]

105. Pereira-Moliner, J.; Claver-Cortés, E.; Molina-Azorín, J.F.; Tarí, J.J. Quality management, environmental management and firm performance: Direct and mediating effects in the hotel industry. J. Clean. Prod. 2012, 37, 82-92. [CrossRef]

106. Llach, J.; Perramon, J.; del Mar Alonso-Almeida, M.; Bagur-Femenias, L. Joint impact of quality and environmental practices on firm performance in small service businesses: An empirical study of restaurants. J. Clean. Prod. 2013, 44, 96-104. [CrossRef]

107. Heras-Saizarbitoria, I.; Boiral, O. ISO 9001 and ISO 14001: Towards a research agenda on management system standards. Int. J. Manag. Rev. 2013, 15, 47-65. [CrossRef]

108. Ahire, S.L.; Golhar, D.Y.; Waller, M.A. Development and validation of TQM implementation constructs. Decis. Sci. 1996, 27, 23-56. [CrossRef]

109. Rahman, S.U. A comparative study of TQM practice and organisational performance of SMEs with and without ISO 9000 certification. Int. J. Q. Reliab. Manag. 2001, 18, 35-49. [CrossRef]

110. Rao, S.S.; Solis, L.E.; Raghunathan, T.S. A framework for international quality management research: Development and validation of a measurement instrument. Total Q. Manag. 1999, 10, 1047-1075. [CrossRef]

111. Woodside, G.; Yturri, J.; Aurricho, P. ISO 14001 Implementation Manual; Butterworth-Heinemann: Boston, MA, USA, 2004.

(C) 2016 by the authors; licensee MDPI, Basel, Switzerland. This article is an open access article distributed under the terms and conditions of the Creative Commons Attribution (CC-BY) license (http://creativecommons.org/licenses/by/4.0/). 